\title{
A little disturbance goes a long way: 33-year understory successional responses to a thin tephra deposit
}

Dylan G. Fischer ${ }^{\mathrm{a}}$, Joseph A. Antos ${ }^{\mathrm{b}}$, William G. Grandy ${ }^{\mathrm{a}}$, Donald B. Zobel ${ }^{\mathrm{c}}$

${ }^{a}$ Evergreen Ecosystem Ecology Laboratory, The Evergreen State College, Olympia, WA

${ }^{\mathrm{b}}$ Department of Biology, University of Victoria, Victoria, British Columbia, Canada

${ }^{\mathrm{c} D e p a r t m e n t ~ o f ~ B o t a n y ~ a n d ~ P l a n t ~ P a t h o l o g y, ~ O r e g o n ~ S t a t e ~ U n i v e r s i t y, ~ C o r v a l l i s, ~ O r e g o n ~}$

Keywords: Disturbance, Mount St. Helens, Old-growth forests, Recovery, Succession, Tephra, Understory 


\begin{abstract}
Large volcanic eruptions can alter forest plant communities through a variety of mechanisms, including direct destruction of forests and changes to forest soils through tephra (aerially transported volcanic ejecta) deposits. While many studies have examined succession following direct destruction of forests, impacts to plant communities through tephra effects are less obvious, especially where the tephra depth is less than plant height. We used a 33-year experiment in an old growth forest that received shallow tephra deposition in the 1980 eruption of Mount St. Helens (WA, USA), to examine plant communities. We determined if community differences between plots with and without tephra: 1) were detectable, and 2) changed over time. We found that plant communities differed significantly between plots with and without tephra after 33 years. Further, differences were stronger after 33 years than at two years following the eruption. Species richness increased over time in both plots with and without tephra, but live cover was largely stable after two years. Nevertheless, communities shifted in different directions over time, where the changes in species composition and abundance immediately following tephra deposition were inconsistent with net changes that occurred over 30 years afterwards. These results suggest that widespread and apparently minor deposits of tephra, usually interpreted to be of transient importance if any, may induce long-term modifications of understory plant communities.
\end{abstract}




\section{Introduction}

The temperate rainforests of the Pacific Northwest (USA) experience frequent and large volcanic eruptions that alter forest plant communities, as dramatically illustrated by the recent and repeated eruptions of Mount St. Helens (Mullineaux, 1986; Dale et al., 2005). Volcanic eruptions can have a wide variety of effects on forest ecosystems, ranging from complete devastation of plant communities to minor ash fall and temporary disruption of air quality (Lipman and Mullineaux, 1981; Turner et al., 1997; Dale et al., 2005; Efford et al., 2014). Vegetation in areas strongly affected by volcanic activity has received substantial study, but comparatively few studies (e.g., Mack, 1981) have examined the effects of minor amounts (< 25mm) of tephra, which can cover larger areas (Zobel and Antos, 1997; del Moral and Grishin, 1999; Bonadonna et al., 2015). Trees can survive tephra deposits of up to $2 \mathrm{~m}$ (Antos and Zobel, 1987; Turner et al., 1997), implying that overstories could remain intact while understory populations are strongly diminished. Volcanic tephra deposition does not usually remove overstory biomass (but see Swanson et al., 2013), and therefore increase light availability or diurnal temperature fluctuations, but it does immediately affect edaphic conditions (Zobel and Antos, 1991a; Ayris and Delmelle, 2012). Thus, tephra deposition provides a useful opportunity to examine forest understory successional patterns in response to disturbance, but with an intact forest canopy.

Long-term studies in tephra impacted forests adjacent to Mount St. Helens have resulted in several lessons about the nature of this disturbance type. Effects of tephra on understory communities may differ from more intense disturbances, which can nearly, or completely, reset succession (Turner et al. 1998; del Moral and Grishin, 1999), and may take time to be realized 
(Antos and Zobel, 2005). For example, species richness is expected to be decreased by more severe volcanic disturbance (mud flows, deep tephra), but not necessarily in shallow tephra (del Moral and Grishin, 1999). Consistent with this expectation, richness declined more in deep than in shallow tephra immediately after the May, 1980 Mount St. Helens eruption, and returned to pre-disturbance values in $4.5 \mathrm{~cm}$, but not $15 \mathrm{~cm}$ tephra deposits (Zobel and Antos in press). For bryophytes, and for vascular growth forms at some sites, percent cover was still expanding 20-30 years after tephra deposition (Antos and Zobel, 2005; Zobel and Antos in press; also see Tsuyuzaki, 2009). Given the decline in effects between sites with 15 versus $4.5 \mathrm{~cm}$ tephra, it is likely that sites with still less tephra will show limited, and different, effects (Zobel and Antos, 1997, in press; Antos and Zobel, 2005). Sites receiving less tephra were generally at lower elevations (Waitt and Dzurisin, 1981) and did not have snowpack, which significantly modified tephra effects at higher elevations (Antos and Zobel, 1982, 2005). Nevertheless, some lasting effects might occur even with thin tephra $(<2.5 \mathrm{~cm})$ via the effects of tephra on soils, given that long-term plant growth can be inhibited by the nitrogen-poor tephra layer that is added to the soil profile (del Moral and Clampitt, 1985). In other systems, manipulative experiments adding shallow tephra have both decreased growth and altered community succession trajectories (Gómez-Romero et al., 2006; Hotes et al., 2010). Following deposition, physical and chemical weathering of the tephra and formation of a new soil layer may continue to change the substrate plants grow in (Dahlgren et al., 1999), providing opportunity for long term community changes (del Moral and Clampitt, 1985; Antos and Zobel, 2005).

It is traditionally accepted that understory succession follows changes in overstory structure, and stabilizes as forest canopies close (Franklin and Dyrness, 1973; Oliver and Larson, 1990). Early theoretical and empirical work (e.g., Bormann and Likens, 1979; Alaback, 1982) 
indicated that understory biomass peaked before the canopy closed, then remained consistently low following canopy closure. After canopy closure, changes in understory communities are typically related to canopy gaps (Van Pelt and Franklin, 2000; Rankin and Tramer, 2002; Grandpre et al., 2011). Nevertheless, some understory successional trends can be difficult to summarize and predict (Pickett et al., 1987). Understory communities should remain stable in old-growth forests over long temporal scales, but recent studies have found a significant decline in species richness through time (Woods et al., 2012; Murphy and McCarthy, 2014), or a lack of relationship between understory metrics and overstory structure (Halpern and Lutz, 2013). Understory plants may respond more to underground competition than light level (e.g., McCune, 1986; Lindh et al., 2003), but it seems likely that stability of canopy structure would result in rather stable conditions belowground. Long-term datasets in temperate forests of the Pacific Northwest, such as those near Mount St. Helens (Zobel and Antos in press), provide a unique opportunity to revisit models of succession because they are paired with disturbance studies. Furthermore, these long term studies provide many advantages over chronosequence studies (Bakker et al., 2002; Halpern and Lutz, 2013), and also allow field-based evaluation of stable states in old growth forest communities, which represent a significant gap in the literature (Schröder et al. 2005).

Our study examines changes in understory community composition after 33 years in a site with shallow tephra $(2.3 \mathrm{~cm})$ from the 1980 eruption of Mount St. Helens in Washington State, USA. We assess understory community changes with (tephra plots) and without tephra (cleared plots), by taking advantage of experimental tephra removal that occurred less than three months after the eruption. For initial post-disturbance response, we re-analyze data from 1980 and 1982 (Antos and Zobel 1985b) and to evaluate long-term changes we use a re-measurement 
of the same plots in 2013. We use a variety of community analysis techniques to address three hypotheses: 1) tephra plots will show more long-term change than cleared plots as they "recover" from the tephra disturbance; 2) the species composition of tephra plots will converge on that of the cleared plots and following 33 years there will be no significant differences in community metrics between treatments given limited initial effects from this minor disturbance and the long recovery period; and 3) cleared (control) plots will have changed very little if any in this oldgrowth forest. In contrast to these hypotheses based on general ideas about minor disturbance and old-growth forests, significant temporal changes in both cleared and tephra plots would highlight dynamism in understory communities, and unique changes in the tephra-impacted plots alone could reflect a legacy effect of tephra deposition 33 years after disturbance.

\section{Methods}

\subsection{Study Design}

Our study took place at 550 m elevation in an old growth stand typical of the Tsuga heterophylla vegetation zone (Franklin and Dyrness, 1973; Swanson et al. 2005). The site was described by Antos and Zobel (1985b, 1987). It is located $39 \mathrm{~km}$ northeast of Mount St. Helens, and received approximately $2.3 \mathrm{~cm}$ of tephra deposit from the 1980 eruption, a low amount compared to areas closer to the volcano or more centrally located in the tephra plume.

In 1980, Antos and Zobel (1985b, 1987) delineated a 1-ha homogeneous stand at the site. All trees $>10 \mathrm{~cm}$ DBH were permanently tagged and measured for diameter in 1980; the trees (primarily Pseudotsuga menziesii and T. heterophylla) were re-measured in 2011 by the HJ Andrews Experimental Forest research program (Pabst et al. unpublished data). 
Within the 1-ha tree stand, Antos and Zobel (1985b) established $1501-\mathrm{m}^{2}$ understory plots along six evenly spaced transects using a stratified random sampling approach with plots located every $3 \mathrm{~m}$ along each transect. Tephra was removed from 50 of the $1-\mathrm{m}^{2}$ plots during August 2-6, 1980. These cleared plots were located along transects that alternated with transects containing undisturbed tephra plots. Tephra was carefully removed using a variety of hand tools, including small excavating implements and brushes, along with a small vacuum cleaner. Most tephra was removed but some sticky tephra was left if removal would have damaged plants. The set of plots resulting from this gentle removal of tephra provided a baseline description of preeruption vegetation, allowing comparison of the effects of tephra deposit with a control. Accordingly, statistical differences in 1980 between cleared and tephra plots were initially interpreted as evidence of the immediate impact of the tephra on plant communities.

Vegetation was first measured on September 4 and 5 following the May 1980 eruption of Mount St Helens, and again between July 21 and 29 in 1982. In September, 2013, we relocated and measured 87 of the $1-\mathrm{m}^{2}$ plots along five transects from the original sampling of 150 plots. Of the 87 relocated plots, 20 were cleared of tephra in 1980 and 67 were original uncleared plots (hereafter referred to as "tephra" plots). Only plots that could be confidently located and identified as matching the original 1980 plot locations were used, hence the discrepancy between the original 150 and current number of plots. We deemed this sampling most appropriate for comparisons because: 1) using the exactly located same plots is critical to effective comparisons, and other plots could not be re-located with confidence, and 2) we chose tephra plots closest to the cleared plots to maximize the relevance of comparisons, abandoning a previously measured transect located down-hill and distant from the other plots. With these data we were able to compare cleared vs. tephra treatments using the same plots measured in 1980, 1982 and 2013. At 
each sampling, all vascular plants were identified to species and the cover determined after all plants have fully grown, but before leaf senescence. In each $1 \mathrm{~m}^{2}$ plot, cover was estimated for each vascular plant species and for major bryophyte taxa, along with total bryophyte cover (Antos and Zobel, 1985b). Nomenclature follows Hitchcock and Cronquist (1973); although some names have been changed, this maintains continuity with earlier reports from this project.

\subsection{The Light Environment}

In July, 1982, a one-day exposure of ozlid paper light meters was used to determine light availability at the soil surface of each plot (sensu Friend 1961; Zobel and Antos 1997). Light intensity, converted from pages exposed to values in microEinsteins, was converted to $\%$ full sun by expressing values as a percentage of light received in a nearby clear-cut with no canopy. Light availability was low throughout the site (Mean $1.93 \%$ of light in full sun, Min: 0.27, Max: $6.15)$ - reflecting the closed canopy of this old-growth forest. Similar data were not available for other years. The 1982 light data were also used in the analysis of 2013 data since light conditions early in secondary succession could be associated with community succession changes $>30$ years later.

\subsection{Statistical Analysis}

To examine differences in diversity among treatments, we compared species richness, Shannon's Diversity $\left(\mathrm{H} ;-\sum\left(\mathrm{P}_{i} * \ln \left(\mathrm{P}_{i}\right)\right)\right.$; where $\mathrm{P}_{i}$ represents the proportional abundance of each

species $i$ ), and Evenness (E; H/ln(richness)). Shannon's Diversity Index was chosen due to its strength highlighting rare species in ecological data (DeJong, 1975). Percent live cover was 
calculated as the summative percent cover of all understory species and byrophytes in each plot. Our data demonstrated deviation from normality based on Shapiro-Wilk W tests. Accordingly, we used a non-parametric re-sampling approach for our analyses. To compare all means for live cover and community diversity metrics we used the non-parametric Approximative Two-Sample Fisher-Pitman Permutation Test to compare across treatment within each year, and across sequential pairs of years within each treatment. We ran the Approximative Two-Sample FisherPitman Permutation Tests in the program R, using the Coin package (Hothorn et al., 2006) with 9,999 permutations. The p-value for each test was calculated based on z-score values in random reshuffling versus our observed values. For the 1982 and 2013 data, we used data on light availability to determine any potential relationships between understory communities and light by conducting simple linear regressions between $\%$ light availability and community diversity metrics.

To visualize and analyze community differences among treatments and years we employed a Nonmetric Multidimensional Scaling ordination (NMS), using the vegan package in the program $R$ (Oksanen et al., 2016; R Core Team, 2015) and a Sørensen (a.k.a. Bray- Curtis) distance measure. Two axes were selected for each ordination based on the least stress configuration after 200 runs. Ordinations were based on percent cover data for each vascular species and total bryophyte cover. To consider treatment differences at a given sampling time, separate ordinations were run for each sample year, and to consider temporal changes, separate ordinations were done through time for cleared and tephra plots. In two dimensional ordinations, 95\% orbitals were produced around the centroid of each group, representative of $95 \%$ confidence for the location of each community in ordination space (using the vegan package in R, Oksanen et al., 2016). Each NMS ordination was followed by a multi-response permutation procedure 
(MRPP) analysis using a Sørenson distance measure. The MRPP uses a randomization procedure to compare multivariate community data, and produce a measure of strength (A value) and a probability value (McCune and Mefford, 2005). We also conducted Dufrene-Legendre Indicator Species Analysis for all comparisons of treatment and year using the "labdsv" package in R (Roberts, 2015). This analysis gave an estimation of fidelity of individual species for categories (year, and treatment), versus random associations in 1000 randomized Monte Carlo iterations (McCune and Mefford, 2005; Roberts, 2015). Finally, light data based on Ozlid paper measurements was fitted to our community profiles for 1982 and 2013 as a vector using the "env.fit" command in the vegan package in R (Oksanen et al., 2016). Vectors are fit using a permutation test (999 permutations) to assess significance, and $\mathrm{r}^{2}$ values for each vector are based on within group and total sums of squares. In all cases, a p-value $<0.05$ was considered significant.

\section{Results}

\subsection{Tree canopy}

The tree size structure changed rather little over the $>30$ year study period in this oldgrowth forest (Fig. 1). In both the original measurements and the recent stand measurements the upper canopy was dominated by large $P$. menziesii with a prominent subcanopy of $T$. heterophylla (Fig. 1), and had a similar tree cohort structure in both surveys. The subtle changes in overstory trees that did occur suggest a typical succession trajectory towards greater dominance by the later succession species, $T$. heterophylla. Through time, both of the dominant tree species increased in size, with average $T$. heterophylla increasing from $\sim 40 \mathrm{~cm}$ in diameter to $\sim 45 \mathrm{~cm}$, and average diameter of $P$. menziesii increasing from $\sim 95 \mathrm{~cm}$ to $\sim 105 \mathrm{~cm}$. There was 
a slight decrease in density of the smallest diameter classes through time, but there was a commensurate increase in large diameter tree density, such that the total stand basal area remained similar. Density of trees >10 cm DBH was $256 \mathrm{ha}^{-1}$ in 1980 and $197 \mathrm{ha}^{-1}$ in $2011(60 \%$ and $63 \%$ Tsuga heterophylla respectively). Basal area was $72.2 \mathrm{~m}^{2} \mathrm{ha}^{-1}$ in 1980 and $71.3 \mathrm{~m}^{2} \mathrm{ha}^{-1}$ in 2011 (74\% and $69 \%$ Pseudotsuga menziesii).

\subsection{Differences between treatments within years}

In 1980 live cover was significantly lower in tephra than in cleared plots $(p=0.001)$, indicating that tephra resulted in immediate damage to some understory plants. However, there were no significant differences in species richness $(p=0.264)$, Shannon's H $(p=0.442)$, or evenness $(p=0.054)$ between treatments (Table 1). Overall, differences between communities in cleared and tephra plots were small but significant as indicated by ordination based on species composition (Fig. 2) and MRPP analysis $(A=0.054, \mathrm{p}=0.001$; Table 2). Indicator species analysis showed that community differences were related to greater cover of bryophytes (up $83 \% ; \mathrm{p}=0.002)$ and salal (Gaultheria shallon; up 29\%; $\mathrm{p}=0.015)$ in cleared plots (Table 3).

By 1982, species richness $(\mathrm{p}=0.041)$ and live cover $(\mathrm{p}=0.018)$ were significantly higher in cleared versus tephra plots, while treatments did not differ significantly in Shannon's H or Evenness (Table 1). In contrast to 1980, however, more holistic comparison of the 1982 communities using ordinations (Fig. 2) and MRPP analyses did not show a significant separation between cleared and tephra plots $(\mathrm{p}=0.200$; Table 2$)$. Indicator species analysis again found that G. shallon showed $33 \%$ greater fidelity toward cleared plots $(\mathrm{p}=0.008$; Table 3).

The long-term effects of the shallow tephra deposit were evaluated by comparing the cleared and tephra plots in 2013. Cleared plots had significantly higher species richness 
( $\mathrm{p}=0.008)$, Shannon's H $(\mathrm{p}=0.005)$, and live cover $(\mathrm{p}=0.008)$ in 2013 ; only species evenness did not differ significantly between treatments (Table 1). Additionally, an MRPP analysis showed a significant separation between treatments $(A=0.010, p=0.012$; Table 2$)$. The NMS ordination showed a much more homogenous grouping for cleared plots than tephra plots (Fig. 2). Indicator species analysis suggested that cleared plots hosted greater fidelity of multiple groups, including total bryophyte cover (61\%), the herbaceous species Tiarella trifoliata (61\%), Viola sempervirens (52\%), and Vancouveria hexandra (34\%), and the woody species Mahonia nervosa (56\%) and Oplopanax horridus (10\%). In contrast, the rapidly spreading, stoloniferous species, Rubus nivalis, had $25 \%$ greater fidelity in the tephra plots (Table 3 ). In sum across these various analyses, tephra and cleared plots were less, not more, similar 33 years after the tephra disturbance than immediately after or 3 seasons later - the opposite of the expectations of "recovery" and no long-term effects.

\subsection{Differences among years}

Temporal changes in the understory community from 1980 to 2013 can indicate the longterm effects (33 years) of the disturbance from tephra deposition. As expected, total live cover in the tephra plots expanded significantly after 1980 , from $25.6 \%$ (CI95\%: 20.7-30.6\%) to $116.2 \%$ (CI95\%: 102.2-130.1\%) within the first three years after the eruption (1980-1982: $\mathrm{p}<0.001)$, but further expansion was not detectable after the next 30 years (1982-2013: $\mathrm{p}=0.654$; Table 1). Species richness also increased between 1980 and 1982 ( $\mathrm{p}<0.001)$, but evenness declined ( $\mathrm{p}$ <0.001). Between 1982 and 2013 though, species richness declined in the tephra plots $(\mathrm{p}=0.012)$, while Shannon's H and species evenness both significantly increased $(\mathrm{p}=0.025$, and $\mathrm{p}<0.001$ respectively). Over-all comparisons of 1980 with 2013 data indicated net increases in species 
richness $(\mathrm{p}=0.004)$, Shannon's H $(\mathrm{p}=0.033)$, and live cover $(\mathrm{p}<0.001)$ in the tephra-impacted plots. Additionally, a MRPP analysis showed a significant separation in the community profile between 1980 and $1982(\mathrm{~A}=0.100, \mathrm{p}=0.001)$ and between 1982 and $2013(\mathrm{~A}=0.070, \mathrm{p}=0.001$; Table 2). These differences were visually evident in an ordination (Fig. 3), where community separation occurred in separate directions for the 1980-1982 comparison (toward the upper right) versus the 1982-2013 comparison (toward the lower left). In the indicator species analysis for tephra plots (Table 3), several taxa had greater fidelity for 1982 versus 1980, including bryophytes (89\%), T. trifoliata (61\%), Adenocaulon bicolor (51\%), V. sempervirens (49\%). Trillium ovatum (19\%), and Pseudotsuga menziesii seedlings (14\%). A new set of species increased from 1982 to 2013 including Achylys triphylla (45\%), G. shallon (30\%), and the rapidly spreading species of Rubus subshrubs or shrubs, $R$. nivalis (22\%), R. specabilis (11\%), and R. ursinus (9\%). Species associated with the 1982 data which decreased by 2013, included bryophytes (64\%), T. trifoliata (55\%), P. menziesii (15\%), Maianthemum dilatatum (13\%), and Taxus brevifolia $(9 \%)$.

Comparison of the cleared plots across the years should indicate patterns in understory succession free from the residual effects of tephra deposition. Live cover and species richness in cleared plots expanded quickly in the first three years even in the absence of tephra ( $p<0.001$; Table 1; sensu Antos and Zobel 1987), while the other diversity metrics remained similar (Shannon's H: p=0.066; Evenness: $\mathrm{p}=0.873$ ). From 1982 to 2013 there was no significant change in richness $(\mathrm{p}=0.342)$ or live cover $(\mathrm{p}=0.424)$, but Shannon's H $(\mathrm{p}=0.011)$, and evenness $(\mathrm{p}=0.0015$, Table 1) increased, similar to the tephra plots. The MRPP analysis showed no significant initial change between 1980 and $1982(\mathrm{p}=0.171)$, but there was a detectable community profile shift between 1982 and $2013(\mathrm{~A}=0.030, \mathrm{p}=0.020)$, and between 1980 and 
2013 ( $\mathrm{A}=0.053, \mathrm{p}=0.001$; Table 2). The NMS ordination (Fig. 3) suggests a unique directionality in the community shift from 1982 to 2013. In addition to positional shifts on the ordination, the cleared plots converge in ordination space with time whereas the tephra plots diverge (note changes in the ellipses on Fig. 3). Although communities did not significantly differ between 1980 and 1982 according to the MRPP analysis, two species had greater fidelity for 1982, $T$. trifoliata (69\%) and A. bicolor (50\%). Indicator species analysis also suggested that community shifts from 1982 to 2013 may have been driven by greater fidelity of $M$. nervosa (79\%) and $A$. triphylla (53\%) for 2013 (Table 3).

While light can have an important effect on understory forest plant community dynamics (Canham et. al 1990), light availability did not vary much between plots (mean $1.93 \%$ full sun, standard deviation $\pm 0.97 \%$ ), and accordingly did not have a strong influence on our data. Relationships between \% full sun and diversity indices in 1982 indicated that both Shannon's H' and evenness were negatively, but weakly, $\left(r^{2}=0.08, p=0.004\right.$, and $r^{2}=0.10, p=0.001$ respectively) related to light availability, but species richness, and percent cover were not related to light in 1982 ( $\mathrm{p}=0.458$ and $\mathrm{p}=0.279$ respectively). Light availability was also a significant, vector in the 1982 community NMS ordination (Fig. $2 ; \mathrm{r}^{2}=0.09, \mathrm{p}=0.023$ ). By 2013, relationships between the community and initial (1982) light availability suggested similar results where Shannon's H' and evenness had negative (but weak) relationships with light availability $\left(\mathrm{r}^{2}=0.05, \mathrm{p}=0.017\right.$, and $\mathrm{r}^{2}=0.09, \mathrm{p}=0.004$ respectively), but species richness $(\mathrm{p}=$ $0.386)$ and total $\%$ cover $(\mathrm{p}=0.558)$ were unrelated to light. By 2013 , the community NMS ordination was also unrelated to light as a vector $(\mathrm{p}=0.54)$.

\section{Discussion}


Our results contribute to two generalizations that are gaining more widespread support: (1) minor disturbance can have long-lasting effects that sometimes amplify instead of dampening with time, and (2) even in old-growth forests, notable successional changes continue in the understory under closed canopies. Our study concerns a forest type that is widespread in the Pacific Northwest (Franlkin and Dyrness 1973). The canopy tree composition here, with Pseudotsuga menziesii forming an upper canopy with abundant Tsuga heterophylla, was typical of the pre-European settlement mesic low- to mid-elevation forests west of the crest of the Cascade Range (Franklin and Dyrness, 1973). Indicator species for change in our study include all four understory growth forms (bryophytes, herbs, shrubs and tree seedlings; Table 3). The disturbance, tephra deposition, is also typical of the region, particularly northeast of Mount St. Helens where the study was located (Shipley and Sarna-Wojcicki, 1983, Zobel and Antos 1997). Areas that receive tephra of this thickness or less make up most of any area subjected to a single tephra deposit. Studies of tephra effects are few, and generally concentrate on areas of moderate to deep deposits. Nevertheless, a few short-term studies of thin deposits of tephra (Hotes et al., 2004; Tsuyuzaki and Hase 2005) or sand (Martínez and Maun, 1999) have also found effects on plant communities, and changes in edaphic factors and resource availability can have persistent effects on plant community assembly (Kardol et al. 2013). For example, even thin deposits of wind-blown dust can add nutrients with potentially long-term effects on ecosystems (Field et al., 2010). Regardless, our data demonstrate how understory comunities can remain dynamic through time in an old-growth forest.

The significant long-term effects we observed underscore the importance of studies over a long time scale. Previous research has repeatedly shown that a long-term perspective is essential for understanding changes in plant communities over time (Brown et al. 2001). After 
thirty years, cover of understory communities with deeper Mount St. Helens tephra was still significantly related to the amount of damage done in 1980 (Zobel and Antos, in press), and disturbance from deep tephra can have effects that last for centuries (Efford et al., 2014). Some responses to disturbance take time to develop (Zobel and Antos, 2016); conclusions based on early sampling may change. For example, delayed responses have previously been observed in response to tephra deposition where plants produced new shoots for the first time after 3-8 growing seasons following burial (Antos and Zobel, 1985a; Zobel and Antos, 1992). Our current study further supports the importance of long term research by showing that decades later even a minor disturbance can have a measurable effect on plant communities. Where tephra was experimentally cleared versus where it was not removed, tephra was associated with changes in forest understory composition. After three decades, differences in community profile became more pronounced and significant between cleared and tephra plots (Fig. 2). After 33 years, the cleared plots increased in diversity and cover when compared to tephra plots. Further, the differences seem to be driven by increases in several herbaceous species and bryophytes in the cleared plots (fragile taxa sensitive to tephra deposition), and the major shrubs (G. shallon and M. nervosa), which may take time to respond to new conditions.

While the effects of deeper tephra can be obvious (Kent et al. 2001; Antos and Zobel, 2005; Ayris and Delmelle, 2012; Efford et al. 2014), long-term effects of shallow tephra deposits may seem more surprising. What mechanisms might produce such a difference in plant performance and thus in community development? Tephra may affect plants by a variety of mechanisms: abrading and adhering to foliage (Seymour et al., 1983; Zobel and Antos, 1985; Segura et al., 1994); mechanical failure from added weight (Mack, 1981); burying seeds and shoots (Antos and Zobel, 1985c, 1987); burial of perennating organs (Zobel and Antos, 1987; 
Zobel and Antos, 2016); changes to soil chemistry resulting from tephra addition (soluble chemical components of tephra may act as toxins, nutrients, or result in complexation of nutrients; Ayris and Delmelle 2012); and modification of the seedbed (Antos and Zobel, 1986; Zobel and Antos, 1991b). In our case, burial by 2-cm tephra is likely to have killed only the smaller bryophytes (Antos and Zobel, 1985b); most herbs at higher elevations easily grow through tephra twice this deep (Antos and Zobel, 1985a, 1985c; Zobel and Antos, 1997). Adherence to foliage impacted viability and growth significantly only for Abies spp. in higher elevation studies (Zobel and Antos, 1985; Segura et al., 1994), but the genus is absent at this site. Rain had washed tephra from shrub leaf surfaces in open areas by mid-June, 1980, and abrasion of leaves in 1980 did not appear to do much damage beyond injury to currently expanding leaves (J. Antos and D. Zobel, personal observation). Most herbs, once buried, can modify their direction and amount of growth to produce aerial shoots and move the perennating organ to the surface (Antos and Zobel 1985a, 1985c). This tephra event produced no measured instances of chemical toxicity to plants. Thus, we are left with few mechanistic hypotheses for how differential changes in plant importance might have been caused beyond mild changes to the competitive and facilitative balance of species in a low light environment. Principally, edaphic changes, and/or changes to the seedbed may be responsible for the patterns we observed. The shallow tephra at our site was probably chemically similar to the deeper tephra we sampled from the May 18 plume, as chemistry was consistent across depths (Waitt and Dzurisin, 1981). Deeper tephra carried substantial soluble nutrients that leached from tephra between 1980 and 1982, and from 1982-1987 (Zobel and Antos, 1991a), notably the elements Ca and K, but new tephra is devoid of $\mathrm{N}$. The tephra may have also represented a unique $\mathrm{P}$ source, and thus altered competitive balance over time as geologically bound $\mathrm{P}$ was released from the tephra (Walker and 
Syers, 1976; Dahlgren et al., 1999). Tephra deposits at our site added over half as much phosphorus per unit weight as was previously present in the mineral soil per unit mass (Zobel and Antos 1991; 5-7 $\mathrm{mg} \mathrm{kg}^{-1} \mathrm{P}$ ). When scaled to area using the bulk density of the tephra (derived from Zobel and Antos 1991), this only represents about 15-21 $\mathrm{mg} \mathrm{P} \mathrm{m}^{-2}$ added to the site, but it still represents a novel input. Nevertheless, it is unclear where tephra-derived P respresents a viable $\mathrm{P}$ source for plants immediately following deposition due to complex weathering patterns in cold temperate ecosystems, and tephra could also result in lower $\mathrm{P}$ availability (Walker and Syres 1976; Ugolini and Zasoski 1979; Ugolini and Dahlgren 2002). Tephra inputs of $\mathrm{K}$ and $\mathrm{Ca}$ may also have been significant compared to mineral soil at 4-9 $\mathrm{mg} \mathrm{kg}^{-}$ ${ }^{1} \mathrm{~K}$, and 27-117 $\mathrm{mg} \mathrm{kg}^{-1} \mathrm{Ca}$ (Zobel and Antos 1991). Although we have no evidence for differential responses among species to such chemical changes in the rooting medium, this remains a promising hypothesis for compositional changes. Another possibility may be changes in soil water and temperature associated with the mulching and insulating effects of this pumicebased tephra (J. Antos and D. Zobel, unpublished data). Burial that reduced bryophyte cover would also alter the seedbed. Changes in the seedbed may have been important for a few species that reproduced primarily by seed (Antos and Zobel, 1986); for example, in deeper tephra, the ratio of established Tsuga to Abies seedlings increased (Zobel and Antos, 1991b). The effectiveness of converting flowering events to seedlings, which may be governed by seedbed properties, was associated with the increase in plant density after 20 years in deeper tephra (Zobel and Antos 2007).

Differences between tephra and cleared plots due to differences in soil composition may have not had time to take effect by 1982 (e.g., del Moral and Clampitt, 1985; Zobel and Antos, 1991a). The infertility of tephra illustrated by del Moral and Clampitt (1985) could explain the 
increase in Rubus spp. in 2013 tephra plots as displayed by our indicator species analysis. Rubus, a clonal genus, may have an advantage over other plants in the infertile tephra-laden soil due to its ability to spread asexually via stolons (Halpern, 1989; Callaghan et al., 1992; Zobel and Antos, 1997, 2009), and show strong recruitment in disturbed sites (Eriksson and Ehrlén, 1992).

Richness and evenness would be expected to increase as plants regrow that were mostly covered by tephra. The increase in species richness through time that we observed is consistent with other studies, where species that lost cover subsequently increased via emergence of new shoots through the deposit or seedling establishment on top of the tephra (Zobel and Antos, 1997). Increases in post-eruption species richness may be matched by the expansion in live cover as the plants recover, resulting in increased evenness after an initial increase in richness. Our results support this pattern where initial increases in species richness are followed by subsequent increases in both evenness and Shannon's H diversity.

Also surprising, were the increases in richness, Shannon's H, and species evenness over time in both tephra and cleared plots. Thus, an alternative interpretation of these data is that the tephra plots and the cleared plots have been placed on separate succession trajectories, and both disturbed and undisturbed plots are dynamic through time. Of course, even our experimental clearing represents a minor disturbance, and our results should be interpreted accordingly. Nevertheless, cleared plots showed less variability than the tephra plots, and they are clearly less heterogeneous in the NMS ordination, especially at the final sampling (Fig. 2). This indicates that while both treatments had a similar increase and subsequent decrease in species richness, the effects of the tephra have resulted in greater variability among plots. This could be a result of greater niche vacancy in the tephra plots. Subsequent stochasticity in dispersal and vegetative expansion processes may have increased differences between plots. It may be that initially, only 
small bryophytes were reduced, and initial recovery looked rapid (Antos and Zobel 1985b), but over time minor competitive gains made by species more tolerant or resilient to the deposition event (e.g., Zobel and Antos 1997) lead to a competitive advantage in this low-light environment.

While historic focus on old-growth understory communities often has assumed stability in the later stages of forest succession, our data suggest that understory communities in an old growth forest are dynamic both in the presence and absence of tephra deposits. Our community analysis suggests that the entire community was shifted mildly following the eruption, but rather than changing back to some original condition (as suggested by the 1980-1982 cleared plot data), a new successional trajectory appeared between 1982 and 2013. These patterns suggest understory communities in old-growth forests are dynamic and seemingly minor disturbances can have lasting effects that do not necessarily dampen out with time (potentially indicative of alternative stable states; Beisner et al., 2003). Attempts to manage old forests should not be based on a steady-state paradigm (Folke et al., 2004), but embrace the concept that forest are ever changing and that minor disturbances can have non-trivial effects.

\section{Acknowledgements}

Sampling in 1980-82 was supported by the National Science Foundation (DEB-8020866 and DEB-8109906) and the US Forest Service. Tree size data for 2011 were provided by the HJ Andrews Experimental Forest research program, funded by the National Science Foundation's Long-Term Ecological Research Program (DEB 0823380), US Forest Service Pacific Northwest Research Station, and Oregon State University. We thank Paul Przybylowicz and members of The Evergreen State College undergraduate program Temperate Rainforests (2013) for field data 
collection and extensive discussion of results on a plot by plot basis. We also thank the Evergreen Computer Applications Lab and Evergreen Lab Stores for providing equipment, and members of the Evergreen Field and Ecosystem Ecology Laboratory for providing extensive feedback on the manuscript and data analysis. We also thank Mark Adams and two anonymous reviewers for providing feedback and suggestions which significantly improved this manuscript.

\section{References}

Alaback, P., 1982. Dynamics of understory biomass in Sitka spruce - western hemlock forests of southeast Alaska. Ecology. 63, 1932-1948.

Antos, J.A., Zobel. D.B., 1982. Snowpack modification of volcanic tephra effects on forest understory plants near Mount St. Helens. Ecology. 63, 1969-1972.

Antos, J.A., Zobel, D.B., 1985a. Upward movement of underground plant parts into tephra deposits from Mount St. Helens. Can. J. Bot.. 63, 20912096.

Antos, J.A., Zobel, D.B., 1985b. Recovery of forest understories buried by tephra from Mount St. Helens. Vegetatio. 64, 103-111.

Antos, J.A., Zobel, D.B., 1985c. Plant form, developmental plasticity, and survival following burial by volcanic tephra. Can. J. Bot. 63, 2083-2090.

Antos, J.A., Zobel, D.B., 1986. Seedling establishment in forests affected by tephra from Mount St. Helens. Am. J. Bot. 73, 495-499. 
Antos, J.A., Zobel, D.B., 1987. How plants survive burial: A review and initial responses to tephra from Mount St. Helens. In: Mount St. Helens 1980: Botanical Consequences of the Explosive Eruptions, D.E. Bilderback (ed).pp. 246-261. University of California Press, Berkeley,

Antos, J.A., Zobel, D.B. 2005. Plant responses in forests of the tephra-fall zone. In: Dale, V., F. Swanson, and C. Crisafulli (eds.) Ecological responses to the 1980 eruption of Mount St. Helens, pp. 47-58. Springer, New York. NY.

Ayris, M.P., Delmelle P., 2012. The immediate environmental effects of tephra emission. Bull. Volcanology 74, 1905-1936.

Bakker J.P., Marrs, R.H., Pakeman, R.J., 2002. Long-term vegetation dynamics: successional patterns and processes. Introduction. Appl. Veg. Sci. 5, 2-6.

Beisner, B.E., Haydon, D.T., Cuddington, K., 2003. Alternative stable states in ecology. Front. Ecol. Environ. 7, 376-382.

Brown, J.H., Whitham, T.G., Ernest, S.M., Gehring, C.A., 2001. Complex species interactions and the dynamics of ecological systems: long-term experiments. Science 293, 643-650.

Bonadonna, C., Costa, A., Folch, A., Koyaguchi, T., 2015. The Encyclopedia of Volcanoes. Encycl Volcanoes. doi: 10.1016/B978-0-12-385938-9.00033-X

Bormann, F.H., Likens, G.E., 1979. Pattern and process in a forested ecosystem. SpringerVerlag, New York.

Callaghan, T.V., Carlsson B.Å., Jónsdóttir I.S., Svensson B.M., Jonasson, S., 1992. Clonal Plants and Environmental Change: Introduction to the Proceedings and Summary. Oikos 63, $341-347$ 
Canham, C.D., Denslow, J.S., Platt, W.J., Runkle, J.R., Spies, T.A., White, P.S., 1990. Light regimes beneath closed canopies and tree-fall gaps in temperate and tropical forests. Can. J. For. Res. 20, 620-631.

Dahlgren, R.A., Ugolini, F.C., Casey, W.H., 1999. Field weathering rates of Mt. St. Helens tephra. Geochim. Cosmochim. Acta 63, 587-598.

Dale, V., Swanson, F., Crisafulli, C., 2005. Ecological responses to the 1980 eruption of Mount St. Helens. Springer, New York. NY.

DeJong, T.M., 1975. A comparison of three diversity indices based on their components of richness and evenness. Oikos, 26, 222-227.

del Moral, R., Clampitt C.A., 1985. Growth of native plant species on recent volcanic substrates from Mount St. Helens. Am. Midl. Nat., 114, 374-383.

del Moral, R., Grishin, S.Y., 1999. Volcanic disturbances and ecosystem recovery. pp. 137-160, In: L. R. Walker, (ed), Ecosystems of Disturbed Ground. Elsevier, New York, NY

Efford, J.T., Clarkson, B.D., Bylsma, R.J., 2014. Persistent effects of a tephra eruption (AD 1655) on treeline composition and structure, Mt Taranaki, New Zealand. New Zeal. J. Bot. 52, 245-261.

Eriksson O., Ehrlén J., 1992. Seed and microsite limitation of recruitment in plant populations. Oecologia 91, 360-364

Field, J.P., Belnap, J., Breshears, D.D., Neff, J.C., Okin, G.S., Whicker, J.J., Painter, T.H., Ravi, S., Reheis, M.C., Reynolds, R.L., 2010. The ecology of dust. Front. Ecol. Environ. 8, 423-430. 
Folke, C., S. Carpenter, B. Walker, M. Scheffer, T. Elmqvist, L. Gunderson and C.S. Holling. 2004. Regime shifts, resilience, and biodiversity in ecosystem management. Annu. Rev. Ecol. Evol. S 35, 557-581.

Franklin, J.F., Dyrness, C.T., 1973. Natural vegetation of Oregon and Washington. U.S. Dept. Ag. For. Serv. Gen. Tech. Rep. PNW-8. Washington DC.

Friend, D.T.C., 1961. A simple method of measuring integrated light values in the field. Ecology 42, 577-580.

Gómez-Romero, M., Lindig-Cisneros, R., Galindo-Vallejo, S., 2006. Effect of tephra depth on vegetation development in areas affected by volcanism. Plant Ecol. 183, 207-213.

Grandpré, L., Boucher, D., Bergeron, Y., Gagnon, D., 2011. Effects of small canopy gaps on boreal mixedwood understory vegetation dynamics. Community Ecol. 12, 67-77.

Halpern, C.B., 1989. Early successional patterns of forest species: Interactions of life history traits and disturbance. Ecology 70, 704-720.

Halpern, C.B., Lutz, J.A., 2013. Canopy closure exerts weak controls on understory dynamics: a 30-year study of overstory-understory interactions. Ecol. Monogr. 83, 221-237.

Hitchcock, C.L., Cronquist, A., 1973. Flora of the Pacific Northwest. University of Washington Press, Seattle, Washington, USA.

Hotes, S., Poschlod, P., Takahashi, H., Grootgans, A.P., Adema, E., 2004. Effects of tephra deposition on mire vegetation: a field experiment in Hokkaido, Japan. J. Ecol. 92, 624634. 
Hotes, S., Grootjans, A.P., Takahashi, H., Ekschmitt, K., Poschlod, P. 2010. Resilience and alternative equilibria in a mire plant community after experimental disturbance by volcanic ash. Oikos 119, 952-963.

Hothorn, T., Hornik, K., van de Wiel, M.A., Zeileis, A., 2006. A lego system for conditional inference. Am. Statistician 60, 257-263.

Kardol, P., Souza, L., Classen, A.T.. 2013. Resource availability mediates the importance of priority effects in plant community assembly and ecosystem function. Oikos 122, 84-94.

Kent, M., Owen, N.W., Dale, P., Newnham, R.M., Giles, T.M., 2001. Studies of vegetation burial: a focus for biogeography and biogeomorphology? Prog. Phys. Geogr. 25, 355482.

Lindh, B.C., Gray, A.N., 2003. Responses of herbs and shrubs to reduced root competition under canopies and in gaps: a trenching experiment in old-growth Douglas-fir forests. Can. J. For. Res. 33, 2052-2057.

Lipman, P.W., Mullineaux, D.R. (Eds.), 1981. The 1980 eruptions of Mount St. Helens, Washington, U.S.G.S. Prof. Pap., 1250., Washington DC.

Mack, R.N., 1981. Initial effects of ashfall from Mount St. Helens on vegetation in eastern Washington and adjacent Idaho. Science 213, 537-539.

Martínez, M.L, Maun, M.A., 1999. Responses of dune mosses to experimental burial by sand under natural and greenhouse conditions. Plant Ecol. 145, 209-219.

McCune, B., 1986. Root competition in a low-elevation grand fir forest in Montana: a trenching experiment. Northwest Sci. 60, 52-54. 
McCune, B, Grace, J., Urban, D.L. 2002. Analysis of ecological communities. MjM software Design. Gleneden Beach, Oregon.

McCune, B., Mefford, M.J., 2005. PC-ORD, Multivariate analysis of ecological data, Version 5 for Windows edition. MjM Software Design, Gleneden Beach, Oregon.

Mullineaux, D.R., 1986. Summary of pre-1980 tephra-fall deposits erupted from Mount St. Helens, Washington State, USA. Bull. Volcanology, 48, 17-26.

Murphy, S., McCarthy, B., 2014. Temporal change in the herbaceous understory community of an old-growth forest: from seasons to decades. Plant Ecol. 215, 221-232.

Oksanen J., Blanchet, F.G., Kindt, R., Legendre, P., Minchin, P.R., O'Hara, R.B., Simpson, G.L., Solymos, P., Stevens, M.H.H., Wagner, H., 2016. vegan: Community Ecology Package. R package version 2.3-5. https://CRAN.R-project.org/package=vegan

Oliver, C.D., Larson, B.C., 1990. Forest stand dynamics. McGraw-Hill, New York.

Pickett, S.T.A., Collins, S.L., Armesto J.J., 1987. Models, mechanisms and pathways of succession. Bot. Rev. 53, 335-371.

R Core Team, 2015. R: A language and environment for statistical computing. R Foundation for Statistical Computing, Vienna, Austria. URL http://www.R-project.org/.

Rankin, W.T., Tramer, E.J., 2002. Understory succession and the gap regeneration cycle in a Tsuga canadensis forest. Can. J. For. Res. 32, 16-23.

Roberts, D.W., 2015. labdsv: Ordination and Multivariate Analysis for Ecology. R package version 1.7-0. http://CRAN.R-project.org/package=labdsv 
Schröder, A., Persson, L., De Roos, A.M., 2005. Direct experimental evidence for alternative stable states: a review. Oikos 110, 3-19.

Segura, G., Brubaker, L.B., Franklin, J.F., Hinckley, T.M., Maguire, D.A., Wright, C., 1994. Recent mortality and decline in mature Abies amabilis: The interaction between site factors and tephra deposition from Mount St. Helens. Can. J. For. Res. 24, 1112-1122.

Seymour, V.A., Hinckley, T.M., Morikawa, Y., Franklin, J.F., 1983. Foliage damage in coniferous trees following volcanic ashfall from Mt. St. Helens. Oecologia 59, 339-343.

Shipley, S., Sarna-Wojcicki. A.M., 1983. Distribution, thickness, and mass of late Pleistocene and Holocene tephra from major volcanoes in the northwestern United States: a preliminary assessment of hazards from volcanic ejecta to nuclear reactors in the Pacific Northwest. U. S. Geol. Surv. Misc. Field Stud. Map MF- 1435. Washington DC.

Swanson, F.J., Crisafulli, C.M., Yamaguchi, D.K., 2005. Geological and ecological settings of Mount St. Helens before May 18, 1980. In: Dale, V., Swanson, F., Crisafulli, C, (eds.) Ecological recovery of Mount St. Helens after the 1980 eruption, pp. 13-26. Springer, New York.

Swanson F.J., Jones J.A., Crisafulli C.M., Lara A., 2013. Effects of volcanic and hydrologic processes on forest vegetation: Chaitén Volcano, Chile. Andean Geol., 40, 359-391.

Tsuyuzaki, S., 2009. Causes of plant community divergence in the early stages of volcanic succession. J. Veg. Sci. 20, 959-969.

Tsuyuzaki S., Hase, A., 2005. Plant community dynamics on the Volcano Mount Koma, northern Japan, after the 1996 eruption. Folia Geobot. 40, 319-330. 
Turner, M.G., Dale, V.H., Everham III, E.H., 1997. Fires, hurricanes, and volcanoes: comparing large disturbances. BioScience 47, 758-768.

Turner, M.G., Baker, W.L., Peterson, C.J., Peet, R.K., 1998. Factors influencing succession: Lessons from large, infrequent natural disturbances. Ecosystems 1, 511-523.

Ugolini, F.C., Zasoski, R.J., 1979. Soils derived from tephra. In: Sheets P.D., Grayson, D.K. (eds) Volcanic activity and human ecology. pp 83-124. Academic Press, New York.

Ugolini, F.C., Dahlgren, R.A., 2002. Soil development in volcanic ash. Global Environmental Research (Eng), 6:69-82.

Van Pelt, R., Franklin, J.F., 2000. Influence of canopy structure on the understory environment in tall, old-growth, conifer forests. Can. J. For. Res. 30, 1231-1245.

Waitt Jr., R.B., Dzurisin, D.R., 1981. Proximal air-fall deposits from the May 18 eruptionstratigraphy and field sedimentology. In: Lipman, P.W., Mullineaux, D.R. (eds.). The 1980 eruptions of Mount St. Helens, Washington. P 601-616. U.S. Geol. Surv. Prof. Pap. 1250. Washington DC.

Walker, T.W., Syers, J.K., 1976. The fate of phosphorus during pedogenesis. Geoderma 15, 119.

Woods, K.D., Hicks, D.J., Schultz, J., 2012. Losses in understory diversity over three decades in an old-growth cool-temperate forest in Michigan, USA. Can. J. For. Res., 42, 532-549.

Zobel, D.B., Antos, J.A., 1985. Response of conifer shoot elongation to tephra from Mount St. Helens. For. Ecol. Manage. 12, 83-91.

Zobel, D.B., Antos, J.A., 1991a. 1980 tephra from Mount St. Helens: Spatial and temporal variation beneath forest canopies. Biol. Fert. Soils 12, 60-66. 
Zobel, D.B., Antos, J.A., 1991b. Growth and development of natural seedlings of Abies and Tsuga in old-growth forest. J. Ecol. 79, 985-998.

Zobel, D. B., Antos J.A., 1992. Survival of plants buried for eight growing seasons by volcanic tephra. Ecology 73, 698-701.

Zobel, D. B., Antos J.A., 1997. A decade of recovery of understory vegetation buried by volcanic tephra from Mount St. Helens. Ecol. Monogr. 67, 317-344.

Zobel, D.B., Antos, J.A., 2007. Flowering and seedling production of understory herbs in oldgrowth forests affected by 1980 tephra from Mount St. Helens. Can. J. Bot. 85, 607-620.

Zobel, D.B., Antos, J.A., 2009. Species properties and recovery from disturbance: Forest herbs buried by volcanic tephra. J. Veg. Sci. 20, 650-662.

Zobel, D.B., Antos, J.A., 2016. Flowering patterns of understory herbs thirty years after disturbance of subalpine old-growth forests by tephra from Mount St. Helens. Int. J. Plant Sci. 177, 145-156.Zobel, D.B., Antos, J.A., In press. Forest understory buried by volcanic tephra: Inertia, resilience and the pattern of community re-development. In: Dale, VH and CM Crisafulli, (eds.), Ecological Responses Revisited 35 years after the 1980 Eruptions of Mount St. Helens. Springer, New York. 
Table 1. Approximative Two-Sample Fisher-Pitman Permutation Test results ( $\mathrm{p}$-values) for pairwise comparisons* of community metrics across treatments and years.

\begin{tabular}{lrrrr}
\multicolumn{5}{c}{ Community Metrics } \\
\hline Groups Compared & Richness & Shannon's H & Evenness & Live cover (\%) \\
\hline 1980 Cleared vs Tephra & 0.264 & 0.442 & 0.054 & $<0.001(\mathrm{C})$ \\
1982 Cleared vs Tephra & $0.041(\mathrm{C})$ & 0.139 & 0.447 & $<0.018(\mathrm{C})$ \\
2013 Cleared vs Tephra & $0.008(\mathrm{C})$ & $0.005(\mathrm{C})$ & 0.140 & $0.008(\mathrm{C})$ \\
Tephra 1980 vs 1982 & $<0.001(1982)$ & 0.883 & $<0.001(1980)$ & $<0.001(1982)$ \\
Tephra 1982 vs 2013 & $0.012(1982)$ & $0.0248(2013)$ & $<0.001(2013)$ & 0.654 \\
Tephra 1980 vs 2013 & $0.004(2013)$ & $0.033(2013)$ & 0.565 & $<0.001(2013)$ \\
Cleared $1980-1982$ & $<0.001(1982)$ & 0.066 & 0.873 & $<0.001(1982)$ \\
Cleared 2013 vs 1982 & 0.342 & $0.011(2013)$ & $<0.001(2013)$ & 0.424 \\
Cleared 2013 vs 1980 & $0.002(2013)$ & $<0.001(2013)$ & $<0.001(2013)$ & $<0.001(2013)$
\end{tabular}

*Parentheses denote which set of plots or year had significantly larger values in each comparison. 
Table 2. Test statistics for pairwise multiple response permutation procedure comparisons of community profile between years and treatments. $\mathrm{P}$ values less than 0.05 were considered significant. For A values, higher numbers represent greater separation between groups.

\begin{tabular}{lcc}
\hline Groups Compared & $\mathrm{A}$ & $\mathrm{p}$ \\
\hline 1980 Cleared vs Tephra & 0.054 & $<0.001$ \\
1982 Cleared vs Tephra & 0.003 & 0.200 \\
2013 Cleared vs Tephra & 0.010 & 0.012 \\
Tephra 1980 vs 1982 & 0.100 & $<0.001$ \\
Tephra 1982 vs 2013 & 0.070 & $<0.001$ \\
Tephra 1980 vs 2013 & 0.049 & $<0.001$ \\
Cleared 1980 vs 1982 & 0.014 & 0.171 \\
Cleared 1982 vs 2013 & 0.030 & 0.020 \\
Cleared 1980 vs 2013 & 0.053 & $<0.001$ \\
\hline
\end{tabular}


Table 3: Significant indicator species for each pairwise comparison of year and treatment.

\begin{tabular}{|c|c|c|c|}
\hline 1980 Only & Group Fidelity & Indicator Value & p-value \\
\hline Bryophytes & cleared & 0.83 & 0.002 \\
\hline Gaultheria shallon & cleared & 0.29 & 0.015 \\
\hline \multicolumn{4}{|l|}{1982 Only } \\
\hline Gaultheria shallon & cleared & 0.33 & 0.008 \\
\hline \multicolumn{4}{|l|}{2013 Only } \\
\hline Bryophytes & cleared & 0.61 & 0.001 \\
\hline Tiarella trifoliata & cleared & 0.61 & 0.002 \\
\hline Mahonia nervosa & cleared & 0.56 & 0.003 \\
\hline Viola sempervirens & cleared & 0.52 & 0.030 \\
\hline Vancouveria hexandra & cleared & 0.34 & 0.039 \\
\hline Oplopanax horridus & cleared & 0.10 & 0.046 \\
\hline Rubus nivalis & tephra & 0.25 & 0.033 \\
\hline
\end{tabular}

Tephra Plots Only, 1980 vs. 1982

Bryophytes 1982

Tiarella trifoliata 1982

Adenocaulon bicolor 1982

Viola.SP 1982

Trillium ovatum 1982

Pseudotsuga menziezii 1982

$\begin{array}{ll}0.89 & 0.001 \\ 0.62 & 0.003 \\ 0.51 & 0.001 \\ 0.49 & 0.038 \\ 0.19 & 0.001 \\ 0.15 & 0.002\end{array}$

Tephra Plots Only, 1982 vs. 2013

Achylys triphylla 2013

Gaultheria shallon 2013

0.45

0.001

Rubus nivalis

2013

0.30

0.002

Rubus specabilis

0.23

0.009

Rubus ursinus

2013

0.12

0.005

Bryophytes

2013

0.09

0.047

Tiarella trifoliata

1982

0.64

0.001

Pseudotsuga menziezii

1982

0.55

0.001

0.15

0.003

Maianthemum dilatatum

1982

0.13

0.031

Taxus brevifolia

1982

0.09

0.031

Cleared Plots Only, 1980 vs. 1982

Tiarella trifoliata

1982

Adenocaulon bicolor

1982
Cleared Plots Only, 1982 vs. 2013

Mahonia nervosa

2013

Achylys triphylla
2013
0.69

0.50

0.040

0.002

0.79

0.013

0.53
0.017 


\section{Figure Captions}

Fig. 1. Stand characteristics through time for the 1-Ha forest plot surveyed in 1980 and again in 2011. Frequency counts are based on $10 \mathrm{~cm}$ diameter classes for each tree at $1.4 \mathrm{~m}$ above the ground surface.

Fig. 2. Non-metric multidimensional scaling (NMS) ordination graph comparing cleared plots and tephra plots, measured in 1980 (top), 1982 (middle), and 2013 (bottom). Each point is an individual plot, and symbols differentiate between treatments. All points represent individual plot measurements, and lines represent $95 \%$ confidence orbitals around the centroid of each group (tephra versus cleared within year). In 1982, a vector was fit to the ordination representing the directional correlation of light measurements with the data.

Fig. 3. Non-metric multidimensional scaling (NMS) ordination graphs showing how tephraimpacted and cleared plots changed through time over 33 years following the eruption. Each point is an individual plot, and symbols differentiate between years. Panels represent cleared (top) and tephra (bottom) plots. All points represent individual plot measurements, and lines represent $95 \%$ confidence orbitals around the centroid of each year within treatment. 
Fig.1

CR Old Growth Stand, 1980-2011

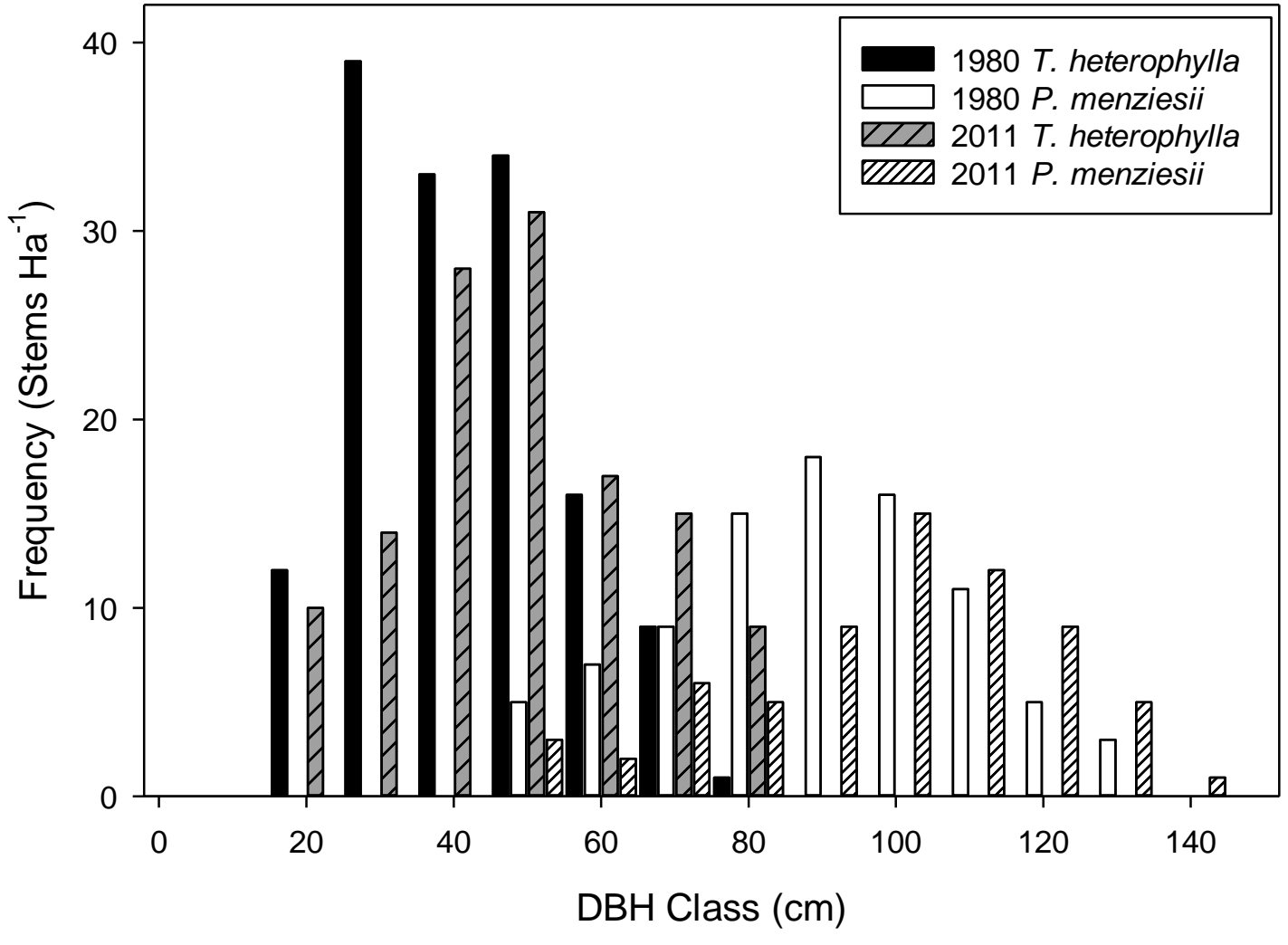


Fig. 2

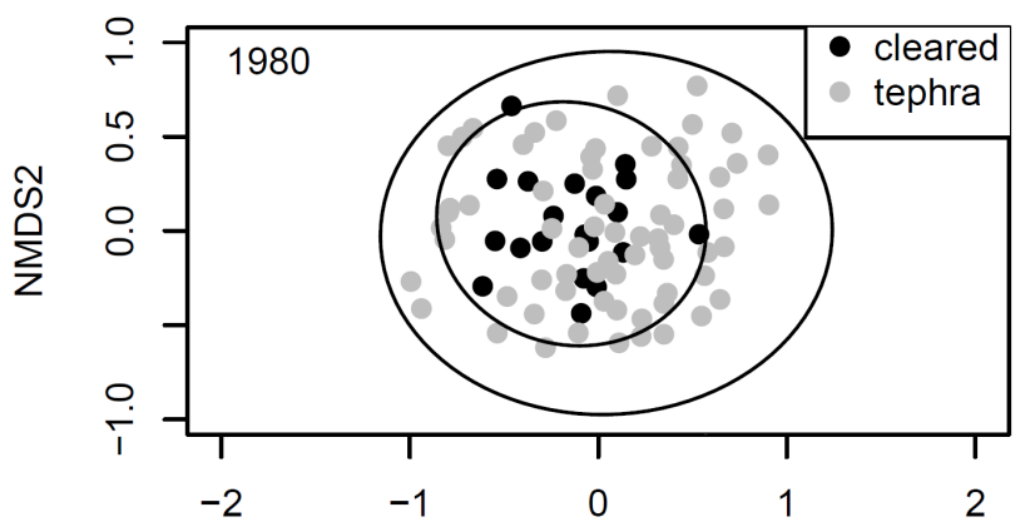

NMDS1

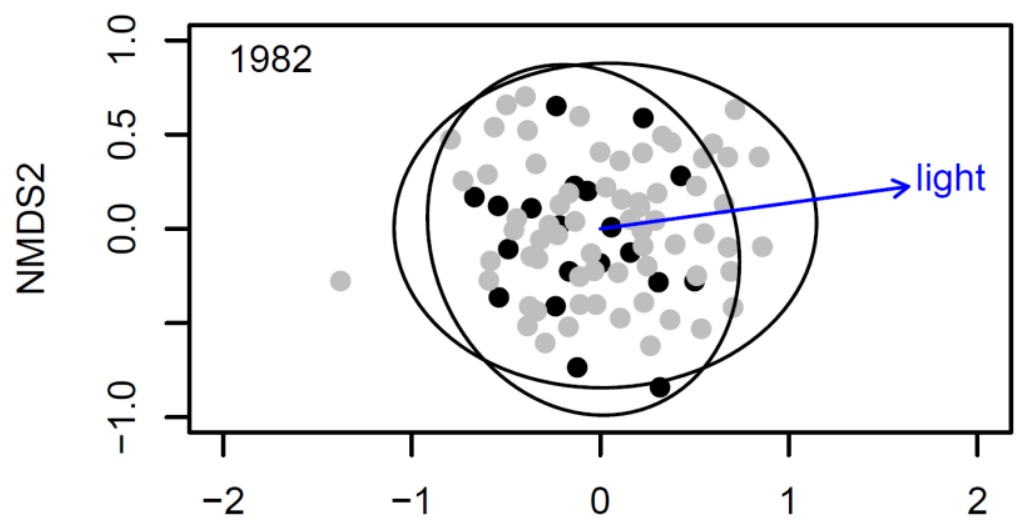

NMDS1

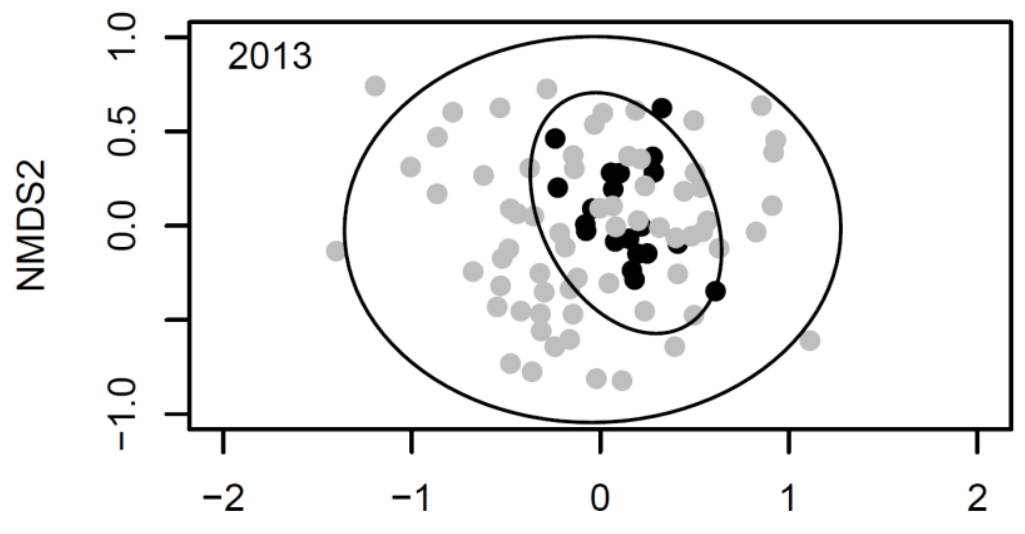

NMDS1 
Fig. 3

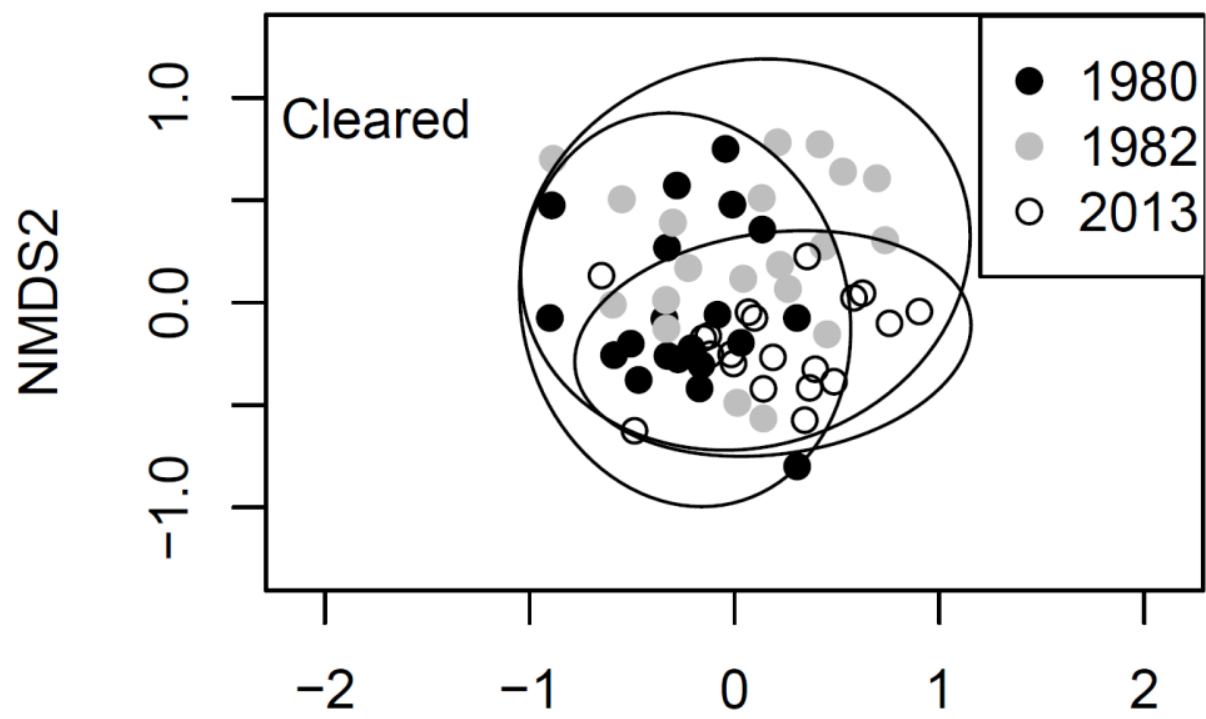

NMDS1

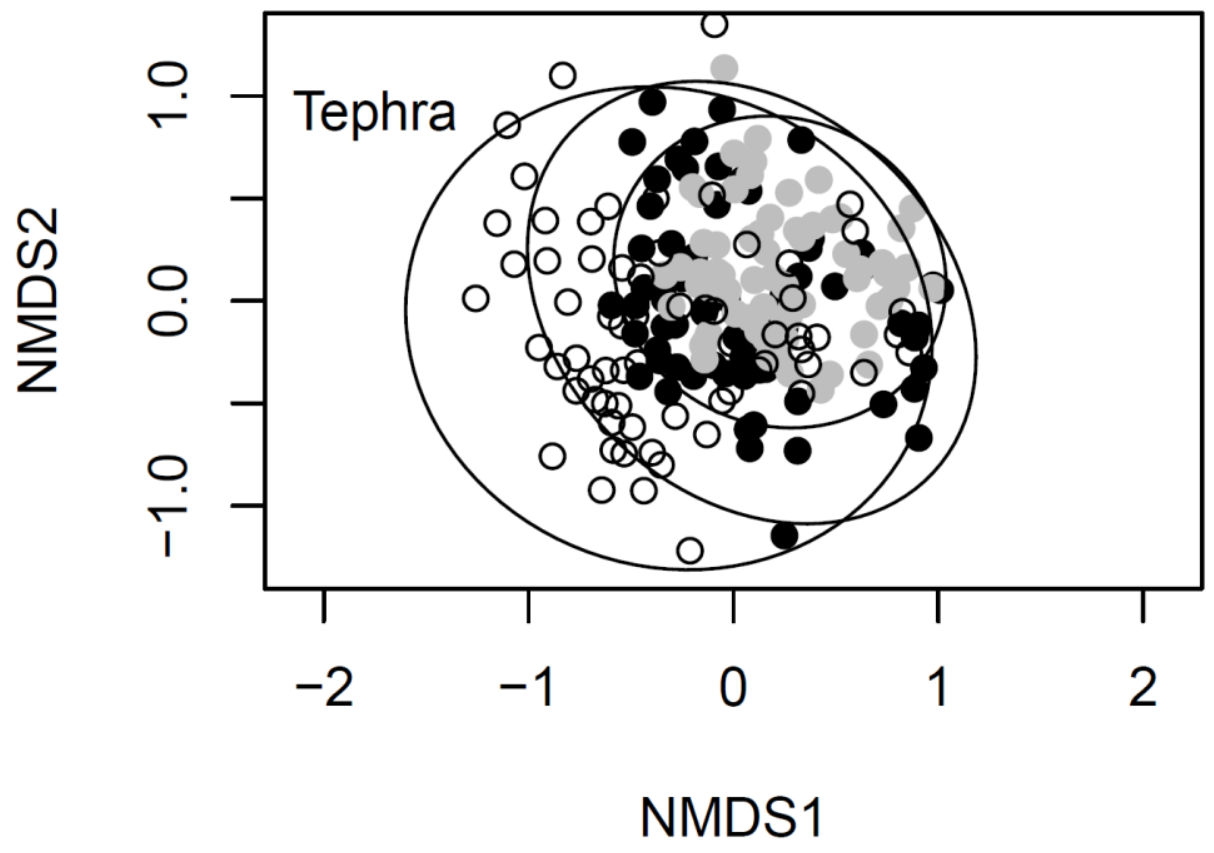

